\title{
Comparative proteome analysis and thermal stress induced changes in the embryo of poly-and bi-voltine strains of Bomby $x$ mori
}

\author{
Punyavathi, Muzafer A. Bhat, Manjunatha H. Boregowda* \\ Proteomics and Genomics Laboratory, Department of Studies in Sericulture Science, University of Mysore, Mysore 570006, Karnataka, India.
}

\begin{tabular}{l}
\hline ARTICLE INFO \\
\hline Article history: \\
Received on: $14 / 10 / 2016$ \\
Accepted on: 06/12/2016 \\
Available online: $20 / 03 / 2017$ \\
\hline Key words: \\
Bombyx mori, Densitometry, \\
Embryo, Global warming, \\
Heat shock, Proteome.
\end{tabular}

\section{ARTICLE INFO}

Article history:

Accepted on: 06/12/2016

Key words

Heat shock, Proteome.

\begin{abstract}
Proteins are the ultimate operating molecules producing the physiological effect in all the stages of an organism. As a consequence, proteome of the embryo play a pivotal role in determining the biological structures besides cellular organization and morphogenetic movements that occur during embryo development. But, changes in the environment temperature for few hours whether that alter the embryo development, protein expression and hatching of infants are unknown in Bombyx mori L. Hence, eggs of poly- and bi-voltine breeds were exposed to heat shock temperature of 35,40 and $45^{\circ} \mathrm{C}$ for $2 \mathrm{~h}$ to measure tolerance level and differential expression of proteins in different age of the embryos. To facilitate comparative analysis among different breeds a comprehensive proteome map was constructed considering protein profile of different day's embryos. Interestingly, $\sim 10$ to 21 protein bands were recorded during embryo development - from ovipostion till hatching along with few new protein bands on day-6, which were differ in their intensity in different silkworm strains. Interestingly, no change in the protein pattern was observed in different days embryos exposed to thermal stress at 35 and $40^{\circ} \mathrm{C}$. But degradation of 18 and $19 \mathrm{kDa}$ proteins were recorded in all the days of embryos exposed to $45^{\circ} \mathrm{C}$ while four major protein bands remain unaltered. Further, the percent of hatching was slightly declined in 35 and $40^{\circ} \mathrm{C}$ and zero hatching was recorded in all the stages of eggs $\mathrm{HS}$ at $45^{\circ} \mathrm{C}$. This clearly indicates that differential expression/degradation of proteins as a response to thermal stress not only influences the growth and development but also determine hatching of embryo. Accordingly, we suggest that embryonic protein map constructed in the present study shall be a valid reference for comparative analysis and hatching of embryos as one of the key traits to measure the rate of thermotolerance in the existing or new strains/breeds of B. mori.
\end{abstract}

\section{INTRODUCTION}

Abiotic stress response has become an indispensable field of research in recent years due to ongoing climate change in order to understand its effect on the health and behavior of animals [1]. Insects, in particular, are known to have a pervasive effect of temperature, which varies with the different life stages because they inhabit different microhabitates and may differ in tolerance to high temperature. Among beneficial insects, the mulberry silkworm, Bombyx mori L. has actually deprived an opportunity to acquire tolerance to hot environmental conditions due to intensive and careful domestication over centuries. This feature is more pronounced in all the stages of bivoltine (temperate origin with low tolerance to high temperature but produces good quality

\footnotetext{
* Corresponding Author

Email: manjunathahb @ gmail.com
}

cocoon/silk) compared to polyvoltine (tropical origin with more tolerance to high temperature but produces low quality cocoon/silk) silkworm strains/breeds. Among many factors attributed to poor performance of bivoltine breeds under tropical condition, unlike other organisms that refers to survivability alone, the major one is lack of innate and/or acquired tolerance to heat stress while cocoon traits decline sharply when larvae are reared at higher temperature [2]. But till date the successful cocoon production all through the year is mainly because importing tolerance to high temperature and better cocoon traits to F1 hybrid by crossing female parent of polyvoltine with male parent bivoltine respectively. Nevertheless, the cocoon/silk quality and yield thus produced are inferior to those of temperate silkworm breeds. To overcome this bottle neck problem, concerted efforts made to fix better cocoon (economic) traits with tolerance to high temperature character in a breed through conventional breeding strategies, which involves tedious and prolonged procedures, did not yield expected outcome. 
Hence, an alternate strategy is warranted for the development of silkworm strain/breed, which would acquire tolerance to harsh climatic conditions due to global warming.

Towards this, the genetic potential of silkworms to acquire tolerance to hot climatic conditions by expressing gene/genes has been studied in the larval stage than the egg stage of $B$. mori [3]. However, the magnitude of embryonic cells that determine the larval, cocoon, pupal and adult traits although has been well documented using ionizing and non-ionizing radiations [4] but their response to thermal stress remains unexplored in $B$. mori.

The genetic framework of the embryo that governs the post-embryonic traits is well demonstrated by irradiating defined region of the egg using UV laser [5]. In addition, protein and structural changes induced not only at the embryonic stage but also at larval stage due to UV laser treatment $[6,7]$ substantiated the role of embryonic cells in determining and manifestation of the post-embryonic traits of $\mathrm{B}$. mori. Moreover, exposure of rat embryos to the elevated temperature $43^{\circ} \mathrm{C}$ for about $7 \mathrm{~min}$ induced craniofacial defects while nonteratogenic heat shock $\left(42^{\circ} \mathrm{C}\right.$ for 10 min) cause embryos to acquire thermotolerance. The resulting acquired tolerance is effective in protecting the rat embryos from subsequent critical temperature conditions [8]. Surprisingly, such studies have not been undertaken to assess inbuilt or acquired tolerance level in the embryos while most of the reports are confined to larval stage of $B$. mori.

Basically, like all homometabolus insects, B. mori eggs cannot thermoregulate and mainly rely on cellular mechanisms to survive under thermal stress. Moreover, development and survival of eggs depends mainly on local temperature; the conditions that eggs experience affect the larvae that they produce. For example, hatchlings from warmer eggs are smaller and have slower initial growth rate [9], but at constant temperature $\geq 32^{\circ} \mathrm{C}$ the eggs of Manduca sexta do not develop successfully. Thus, development and survival at higher temperatures strongly depend on each life stage, while larvae develop successfully and rapidly at constant temperature $\left(\geq 32^{\circ} \mathrm{C}\right)$ that cause complete mortality in eggs [10]. In view this fact, in the present study we have focused on egg stage to report basically the proteome pattern of different silkworm strains for comparative analysis and differential expression of protein in response to HS that alter the embryonic development and death, which was assessed based on hatching of eggs as an index.

\section{MATERIALS AND METHODS}

\subsection{Silkworm Eggs}

Newly emerged moths of $B$. mori representing Polyvoltine - Daizo and Pure Mysore, Bivoltine - $\mathrm{NB}_{4} \mathrm{D}_{2}$ and $\mathrm{CSR}_{2}$ and sex limited at larval stage - pere were used for the preparation of loose eggs by self-crossing of moths. After ovipostion, all the eggs were treated with salt solution of 1.08 specific gravity to separate the fertilized eggs from unfertilized eggs, wherein the fertilized eggs sink and the unfertilized and dead eggs were float in the solution due to high and low specific gravity respectively [11].
The resultant fertilized eggs of bivoltine breeds were subjected for cold acid treatment ( $1.1 \mathrm{sp}$. gr. $\mathrm{HCl} ; 25^{\circ} \mathrm{C}$ for $45 \mathrm{mins}$ ) not only to prevent the embryos enter into diapause but also avoid pre heat shock in case of hot acid treatment.

\subsection{Induction of thermal stress}

Thermal stress was induced at 35,40 and $45^{\circ} \mathrm{C}$ by placing plastic vials containing eggs of different strains separately in the water bath for $2 \mathrm{~h}$ followed by $2 \mathrm{~h}$ recovery period in room temperature. 50 eggs in each replication were exposed to different HS temperatures from day-2 after oviposition till blue egg stage at $24 \mathrm{~h}$ intervals. Concomitantly, a batch in three replications was maintained as control in natural environmental conditions prevailed in the rearing house that ranges from 28 to $31^{\circ} \mathrm{C}$ with relative humidity of 56 to $67 \%$ to evaluate the impact of HS and fluctuating environmental condition on embryonic development and hatching. Such experiments were performed for six times.

\subsection{Embryonic response to heat stress}

Sensitivity to varied HS temperatures was measured based on percent of hatching as an index of embryonic development. The hatching of embryos of all the six experiments was pooled to draw an average percent of hatching for each HS treatment and silkworm breed.

\subsection{Analysis of egg protein}

Eggs derived from each set exposed to different HS temperatures and control groups in their different days (from day-2 after oviposition till blue egg stage at $24 \mathrm{~h}$ intervals) were homogenized separately with $30 \mu \mathrm{l}$ Tris- $\mathrm{HCl}$ buffer $(50 \mathrm{mM}$ Tris buffer - pH 6.8, 1mM PMSF, 100mM DTT). The homogenate was centrifuged at $3000 \mathrm{rpm}$ for $10 \mathrm{~min}$ at $4{ }^{\circ} \mathrm{C}$. The resulting protein samples (supernatant) were subjected for quantitative estimation following Lowry's method [12] and OD was measured at $650 \mathrm{~nm}$ in Biophotometer (Eppendorf, Germany). SDS-PAGE was performed as described by Weber and Osborn [13] with suitable modifications as established in our laboratory [14]. Briefly, $20 \mu \mathrm{l}$ of protein sample derived from each treatment was mixed with 20 $\mu \mathrm{l}$ of sample buffer containing $4 \%$ SDS, $50 \mathrm{mM}$ Tris- $\mathrm{HCl}(\mathrm{pH}$ 6.8), $\quad 10 \% \quad \beta$-mercaptoethanol, $20 \%$ glycerol and $0.1 \%$ Bromophenol blue.

Each lane of the gel (12 and 15\%) was loaded with equal amount $(40 \mu \mathrm{l})$ of egg protein sample and protein molecular marker in separate lanes. After electrophoresis the gel was fixed in fixative solution (10:30:60 acetic acid: methanol: distilled water) overnight followed by staining in coomassie brilliant blue R-250 for 2-3 $h$.

\subsection{Densitometric analysis}

The images of protein (SDS-PAGE) gel were captured using gel-documentation unit (CSL-MICRODOC System). The protein pattern and density of each protein band was computed using TotalLab Quant software (Version 11.4). 


\subsection{Statistical analysis}

All the data for quantitative estimation of silkworm embryo protein and hatching was computed using SPSS-ANOVA.

\section{RESULTS}

\subsection{Proteome profile and manifestation in the protein due to heat shock}

The protein profile derived from day- 2 to -8 normal embryos of pere, NB4D2, CSR2, Daizo and pure Mysore comprises a total of 10 to 21 discrete bands with rf values 0.0157 to 0.9954 as evidenced in fig. 1 (Table 1). Based on the protein banding and densitometry peak pattern, we have constructed a comprehensive protein map for the embryo poly- and bi-voltine silkworm strains for the first time. The four major protein bands ascribable to vitelline-H (Fig.1a), egg specific protein (Fig.1b), vitelline-L (Fig.1c) and $30 \mathrm{kDa}$ (Fig.1d) despite similar between poly- and bi-voltine silkworm strains but differs in the intensity as evidenced in the proteome map of the embryo established for the first time in the present study considering protein pattern of the normal embryos. Few additional protein bands noticed on day- 6 and day- 8 might an indicator for the development of new organs in the embryo. On the other hand, no expression of HSPs noticed in day- 2 and day- 3 embryos subjected to $\mathrm{HS}$ at 35,40 and $45^{\circ} \mathrm{C}$. But, among different proteins 18 and $19 \mathrm{kDa}$ proteins were found degraded both in poly- and bi-volitine embryos of all days, whereas degradation of $95,90,68,60,58$, and $43 \mathrm{kDa}$ proteins were recorded from day- 6 embryos exposed to $45^{\circ} \mathrm{C}$ (Fig. 2). Interestingly, no noticeable changes observed in any of the protein bands on day- 7 and 8 embryos exposed to $\mathrm{HS}$ at 35,40 and $45^{\circ} \mathrm{C}$ (figures not shown) against non HS induced embryo protein pattern. Comparatively, relative abundance and intensity of normal proteins and synthesis or over expression of HSPs differs distinctly among different days of eggs and silkworm strains.

Table 1: Densitometric analysis of proteome of different strains of Bombyx mori embryo.

\begin{tabular}{|c|c|c|c|c|c|c|c|c|c|}
\hline \multirow{2}{*}{$\begin{array}{c}\text { Day of the } \\
\text { Embryo }\end{array}$} & \multirow[t]{2}{*}{ Strains } & \multicolumn{2}{|c|}{ Peak } & \multirow[t]{2}{*}{ Distance } & \multirow[t]{2}{*}{ Width } & \multirow[t]{2}{*}{ Height } & \multirow[t]{2}{*}{ Area } & \multirow[t]{2}{*}{$\%$} & \multirow[t]{2}{*}{ Rf } \\
\hline & & Mean No. & SD & & & & & & \\
\hline \multirow[t]{5}{*}{2} & pere & 16.667 & 0.577 & $51-1340$ & $03-37$ & $01-049$ & $01-1254$ & $0.1-0.9$ & $0.0374-0.9795$ \\
\hline & NB4D2 & 17.333 & 0.577 & 51-1334 & $03-70$ & 01-084 & $01-4239$ & $0.3-21.4$ & $0.0423-0.9794$ \\
\hline & CSR2 & 10.667 & 0.577 & 08-0398 & $03-10$ & $01-036$ & $01-0205$ & $0.1-12.2$ & $0.0270-0.9954$ \\
\hline & Daizo & 14.000 & 0.000 & $61-1328$ & $03-94$ & 01-086 & $01-7165$ & $0.2-15.2$ & $0.0438-0.9704$ \\
\hline & PM & 10.667 & 1.155 & 08-0406 & $03-40$ & 01-036 & 01-2048 & $0.1-20.9$ & $0.0200-0.9950$ \\
\hline \multirow[t]{5}{*}{3} & pere & 18.000 & 1.732 & $61-1641$ & $03-52$ & 02-087 & $01-1266$ & $0.1-11.0$ & $0.0319-0.8306$ \\
\hline & NB4D2 & 18.000 & 1.732 & $61-1641$ & $03-52$ & 02-087 & $01-1266$ & $0.1-12.2$ & $0.0319-0.8306$ \\
\hline & CSR2 & 11.000 & 0.000 & $37-0401$ & $03-45$ & 02-080 & $02-2359$ & $0.1-30.6$ & $0.0879-0.9525$ \\
\hline & Daizo & 19.333 & 1.154 & $30-1861$ & $04-70$ & $02-087$ & $01-4239$ & $0.2-20.4$ & $0.0157-0.9728$ \\
\hline & PM & 10.000 & 1.000 & $37-1591$ & 03-107 & 02-101 & 01-2359 & $0.1-17.7$ & $0.0692-0.9865$ \\
\hline \multirow[t]{5}{*}{4} & pere & 15.000 & 0.000 & $52-1636$ & $03-45$ & $02-100$ & $01-3081$ & $0.1-13.1$ & $0.0310-0.9750$ \\
\hline & NB4D2 & 14.666 & 0.577 & $52-1636$ & $03-70$ & 02-100 & $02-5094$ & $0.2-15.2$ & $0.0310-0.9750$ \\
\hline & CSR2 & 10.000 & 0.000 & $113-1636$ & $03-86$ & 01-101 & 03-6709 & $0.2-17.3$ & $0.0692-0.9865$ \\
\hline & Daizo & 16.000 & 0.000 & $61-1589$ & $03-20$ & 03-087 & $01-5176$ & $0.1-18.2$ & $0.0319-0.8306$ \\
\hline & PM & 10.000 & 0.000 & $113-1636$ & $03-86$ & 01-083 & 01-6709 & $0.1-17.3$ & $0.0692-0.9865$ \\
\hline \multirow[t]{5}{*}{5} & pere & 12.666 & 0.577 & $82-1354$ & 03-107 & $01-104$ & $01-7377$ & $0.1-18.2$ & $0.0502-0.9896$ \\
\hline & NB4D2 & 13.000 & 0.000 & $98-1354$ & 03-108 & 01-104 & $01-7377$ & $0.1-20.0$ & $0.0602-0.8322$ \\
\hline & CSR2 & 11.003 & 0.577 & $37-1616$ & 03-71 & 01-104 & $01-5565$ & $0.1-17.7$ & $0.0502-0.9896$ \\
\hline & Daizo & 14.666 & 0.577 & $52-1636$ & $03-71$ & 01-100 & $01-5094$ & $0.1-22.3$ & $0.0310-0.9750$ \\
\hline & PM & 11.003 & 0.577 & $37-1616$ & $03-71$ & $01-104$ & $02-5565$ & $0.1-25.2$ & $0.0502-0.9896$ \\
\hline \multirow[t]{5}{*}{6} & pere & 20.333 & 0.577 & $30-1861$ & $04-212$ & $01-103$ & $01-1864$ & $0.2-13.0$ & $0.0157-0.9728$ \\
\hline & NB4D2 & 20.000 & 1.000 & $30-1861$ & 04-212 & 01-103 & 01-1864 & $0.2-18.2$ & $0.0157-0.9728$ \\
\hline & CSR2 & 13.000 & 0.000 & $98-1354$ & 03-102 & 03-101 & 01--7377 & $0.2-15.2$ & $0.0602-0.8322$ \\
\hline & Daizo & 18.000 & 0.000 & $75-1729$ & $03-70$ & 01-084 & $02-4239$ & $0.2-20.0$ & $0.0423-0.9752$ \\
\hline & PM & 13.000 & 0.000 & $98-1354$ & 03-102 & 03-081 & $03-7377$ & $0.2-18.2$ & $0.0602-0.8322$ \\
\hline \multirow[t]{5}{*}{7} & pere & 15.333 & 0.577 & $52-1636$ & $03-45$ & $03-100$ & $01-3081$ & $0.1-13.2$ & $0.0310-0.9750$ \\
\hline & NB4D2 & 15.333 & 0.577 & $52-1636$ & $03-45$ & 03-100 & 01-3081 & $0.1-16.3$ & $0.0310-0.9750$ \\
\hline & CSR2 & 12.666 & 0.577 & $82-1354$ & 03-107 & 01-104 & $01-7377$ & $0.1-15.2$ & $0.0502-0.9896$ \\
\hline & Daizo & 16.666 & 1.155 & $61-1729$ & $03-70$ & 01-087 & $01-4239$ & $0.1-23.0$ & $0.0319-0.9750$ \\
\hline & PM & 12.666 & 0.577 & $82-1354$ & 03-102 & $01-104$ & $01-7377$ & $0.1-29.8$ & $0.0502-0.9896$ \\
\hline \multirow[t]{5}{*}{8} & pere & 21.666 & 0.577 & $85-1849$ & $03-212$ & $01-103$ & $01-1365$ & $0.1-19.1$ & $0.0390-0.9544$ \\
\hline & NB4D2 & 21.666 & 0.577 & $85-1849$ & 03-212 & 01-103 & $01-1365$ & $0.1-20.0$ & $0.0390-0.9544$ \\
\hline & CSR2 & 14.000 & 1.000 & $52-1636$ & 03-102 & 01-102 & $01-7377$ & $0.1-19.2$ & $0.0310-0.9750$ \\
\hline & Daizo & 21.667 & 0.577 & $85-1849$ & $03-212$ & 01-103 & 01-1365 & $0.1-19.1$ & $0.0390-0.9544$ \\
\hline & PM & 14.000 & 1.000 & $52-1636$ & 03-103 & 01-102 & $01-7377$ & $0.1-29.2$ & $0.0310-0.9750$ \\
\hline
\end{tabular}




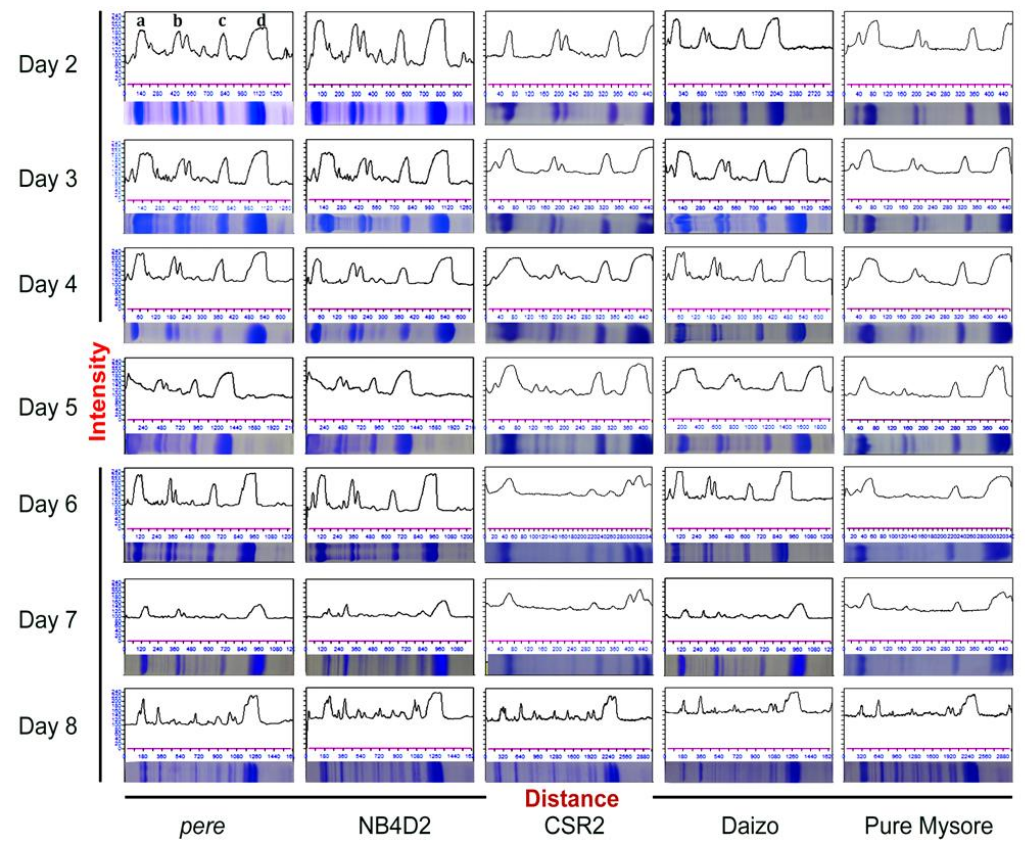

Fig. 1: Proteome map and densitometric analysis in the poly- and bi-voltine silkworm strains of Bombyx mori embryo (a-vitelline-H, b-egg specific protein, c-vitelline-L and d-30 kDa).
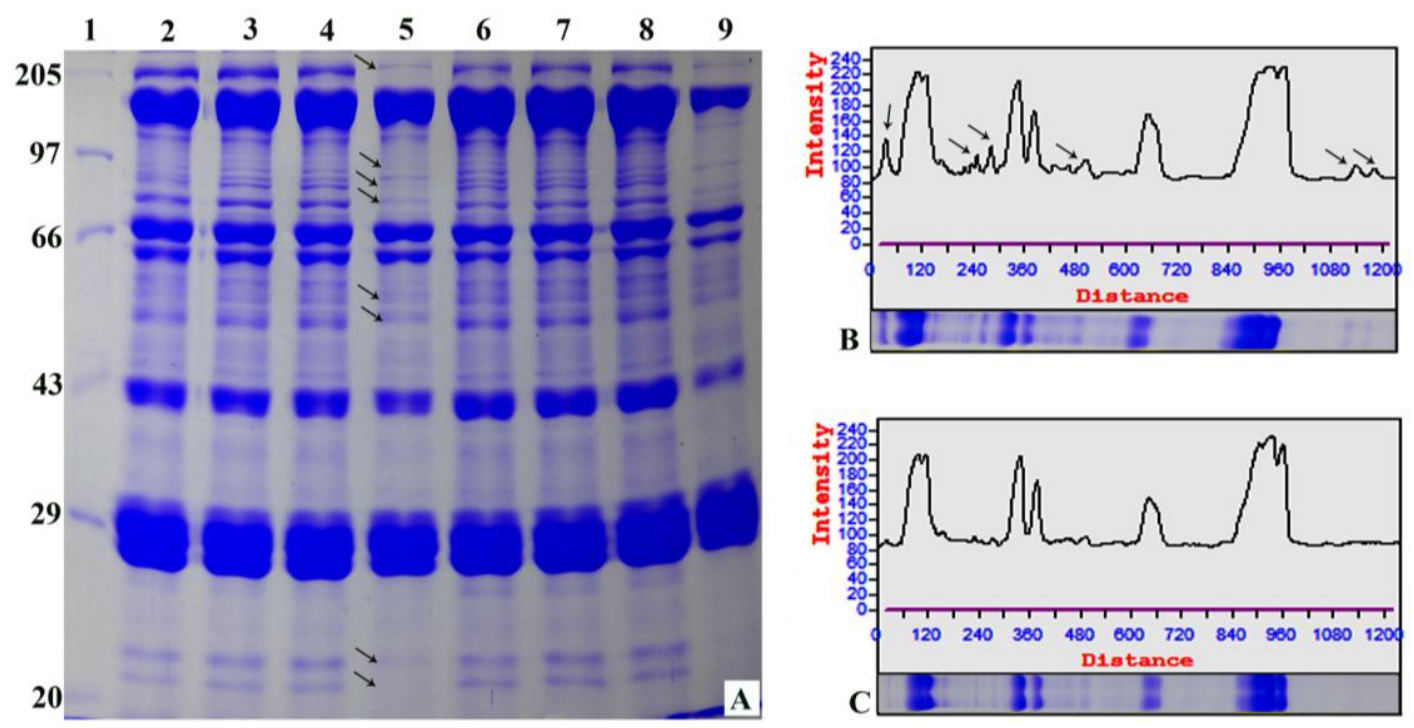

Fig. 2: Changes in the protein profile and densitometric analysis as influenced by heat shock in the day-6 embryo of different strains of Bombyx mori. A: Total protein profile of day 6 embryo. Lane 1 - molecular marker, lanes $2 \& 6$ control, lanes $3 \&$ )

\subsection{Quantitative changes in the total protein content of embryo}

The quantum of protein present in day-2 till day-8 eggs of pere, $\mathrm{NB}_{4} \mathrm{D}_{2}, \mathrm{CSR}_{2}$, Daizo and pure Mysore exposed to varied HS temperatures was compared with their respective controls. Interestingly, the amount of protein content was gradually increased till day- 5 and remains the same on day- 6 of the embryo and decreased thereafter in all the poly- and bi-voltine strains (Fig. 3). Discriminately, the amount of protein was distinct between poly- and bi-voltines measuring $94.17 \mu \mathrm{g} / \mathrm{ml}$ (low) and 97.84 $\mu \mathrm{g} / \mathrm{ml}$ (high) in day-2 normal eggs of PM and NB4D2 respectively. Subsequently, among different days of the embryo highest amount of protein content $240.70 \mu \mathrm{g} / \mathrm{ml}$ and $239.04 \mu \mathrm{g} / \mathrm{ml}$ was recorded in day-5 eggs of NB4D2 and PM respectively. A day before hatching the amount of protein $180.65 \mu \mathrm{g} / \mathrm{ml}$ which is being highest and $158.96 \mu \mathrm{g} / \mathrm{ml}$ lowest was recorded in the eggs of $\mathrm{NB}_{4} \mathrm{D}_{2}$ and $\mathrm{CSR}_{2}$ respectively. Concurrently, the eggs exposed to varied HS temperature exhibited increased and decreased protein content measuring 260.97 , and $254.37 \mu \mathrm{g} / \mathrm{ml}$ in the day- 6 eggs of Daizo and pere $\mathrm{HS}$ at $35^{\circ} \mathrm{C}$ while it was found to decrease in $(91.33 \mu \mathrm{g} / \mathrm{ml})$ in day- 2 eggs of PM at $45^{\circ} \mathrm{C}$ HS compared to their respective controls. Statistically, the changes in the amount of protein recorded in all the embryonic stages under normal and HS conditions were found significant at $p<0.01$ (Table 2). 

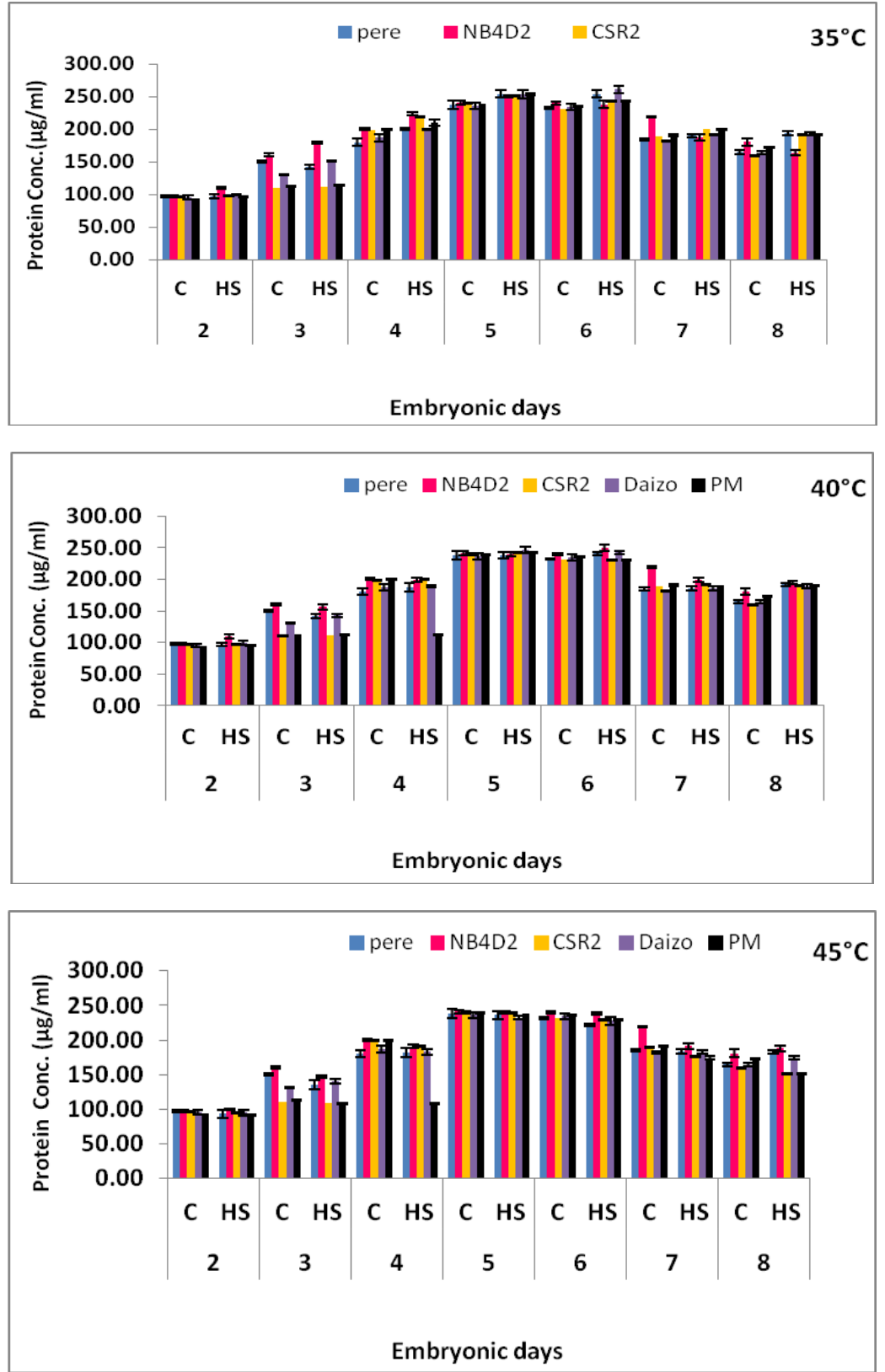

Fig. 3: Changes in the total protein content due to thermal stress during embryonic development in the poly-and bi-voltine silkworm strains of Bombyx mori.

Table 2: Statistical analysis for the total protein content changes due to heat shock during different days of eggs of poly and bivoltine silkworm strains of Bombyx mori.

\begin{tabular}{|c|c|c|c|c|c|c|}
\hline & & pere & NB4D2 & CSR2 & Daizo & PM \\
\hline \multirow{4}{*}{ F- Value } & Replications & 5.7564 & 28.2690 & 5.6899 & 4.1305 & 0.8429 \\
\hline & Temperature & 100.0281 & 83.4047 & 2125.7316 & 128.2274 & 14.3937 \\
\hline & Embryonic Days & 1942.6115 & 5303.3306 & 64756.5016 & 2973.1383 & 286.0968 \\
\hline & Temp. x Embryo Days & 10.2247 & 85.7150 & 291.8337 & 8.0620 & 6.0966 \\
\hline \multirow{3}{*}{ Significance } & Temperature & $*$ & $*$ & $*$ & $*$ & $*$ \\
\hline & Embryonic Days & ** & ** & $* *$ & ** & ** \\
\hline & Temp. x Embryo Days & $*$ & $*$ & $*$ & $*$ & $*$ \\
\hline \multirow{3}{*}{ SE } & Temperature & 0.8806 & 0.4986 & 0.1677 & 0.7172 & 2.5750 \\
\hline & Embryonic Days & 1.1649 & 0.6596 & 0.2219 & 0.9488 & 3.4064 \\
\hline & Temp. x Embryo Days & 2.3299 & 1.3192 & 0.4437 & 1.8976 & 6.8128 \\
\hline \multirow{3}{*}{ CD $5 \%$} & Temperature & 3.2620 & 1.3962 & 0.4696 & 2.0083 & 7.2104 \\
\hline & Embryonic Days & 4.3329 & 1.8470 & 0.6212 & 2.6567 & 9.5385 \\
\hline & Temp. x Embryo Days & 6.5240 & 3.6940 & 1.2424 & 5.3135 & 19.0769 \\
\hline \multirow{3}{*}{ CV1\% } & Temperature & 4.3329 & 1.8545 & 0.6238 & 2.6676 & 9.5775 \\
\hline & Embryonic Days & 3.2753 & 2.4533 & 0.8252 & 3.5289 & 12.6698 \\
\hline & Temp. x Embryo Days & 8.6657 & 4.9066 & 1.6503 & 7.0578 & 25.3396 \\
\hline
\end{tabular}




\subsection{Determination of heat sensitivity}

Eggs of both bi- (pere, $\mathrm{NB}_{4} \mathrm{D}_{2} \& \mathrm{CSR}_{2}$ ) and poly-voltine (Daizo \& pure Mysore) silkworm strains exposed to HS temperatures 35,40 and $45^{\circ} \mathrm{C}$ exhibited diverse response during different stages of embryonic development from day- 2 till a day before hatching of infants. Induction of $\mathrm{HS}$ at 35 and $40^{\circ} \mathrm{C}$ while exhibiting slight decline in the hatching of embryos over control, $45^{\circ} \mathrm{C}$ found lethal as none of the eggs were hatched. Moreover, some of the fully developed embryos either found dead within the chorion shell or midstream of hatching (Fig. 4) upon $\mathrm{HS}$ at $45^{\circ} \mathrm{C}$. Among poly- and bi-voltine strains, a slight improvement in hatching was recorded in the day- 8 embryos of $\mathrm{PM}$ at 35 and $40^{\circ} \mathrm{C}$
HS while higher mortality of $\sim 17 \%$ was recorded from day-2 embryo of pere and $\mathrm{NB}_{4} \mathrm{D}_{2}$, HS at $40^{\circ} \mathrm{C}$ (Fig. 5). Interestingly, embryo mortality was temperature dependent during different days of embryo development in different silkworm strains, wherein the low and high mortality of 0.12 (day- 8 at $35^{\circ} \mathrm{C}$ ) and $17.17 \%$ (day-2 at $40^{\circ} \mathrm{C}$ ) in pere; 0.51 (day- 8 at $35^{\circ} \mathrm{C}$ ) and $17.88 \%$ (day-2 at $40^{\circ} \mathrm{C}$ ) in NB4D2; 3.32 (day- 8 at $35^{\circ} \mathrm{C}$ ) and $9.11 \%$ (day- 2 at $40^{\circ} \mathrm{C}$ ) in CSR2; 1.92 (day-8 at $35^{\circ} \mathrm{C}$ ) and $8.20 \%$ (day-2 at $40^{\circ} \mathrm{C}$ ) in Daizo and 0.25 (day- 6 at $35^{\circ} \mathrm{C}$ ) and $4.44 \%$ (day- 2 at $40^{\circ} \mathrm{C}$ ) in PM was recorded (Fig. 5). Statistically, the percent of hatching recorded in all the embryonic stages of different silkworm strains HS at varying temperature was significant at $p<0.05$ (Table 3 ).

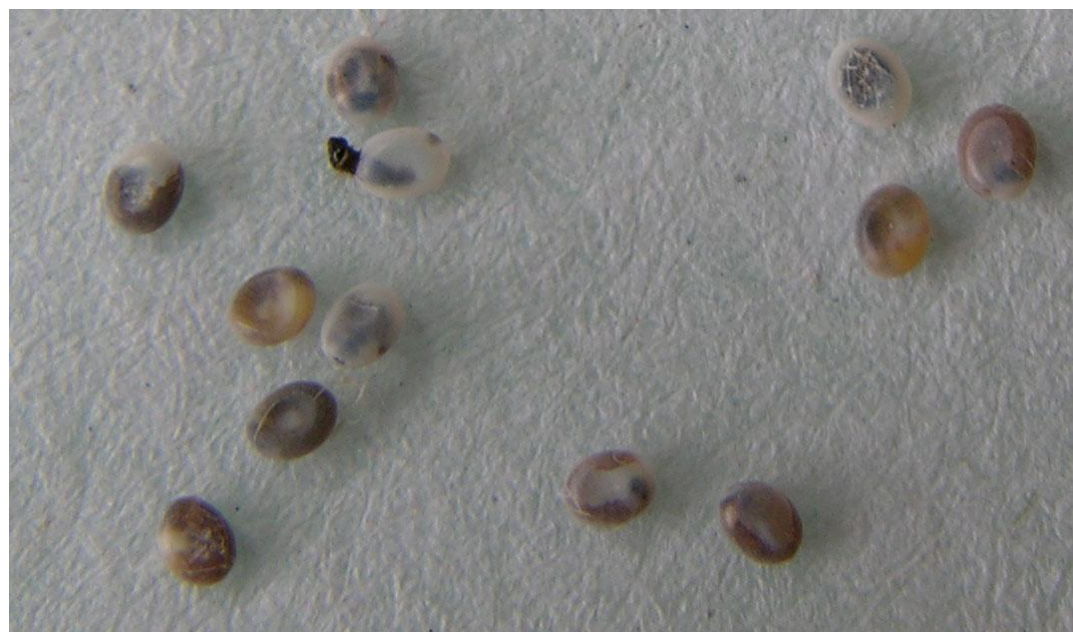

Fig. 4: Embryonic death due to thermal stress in the poly- and bi-voltine silkworm strains of Bombyx mori.
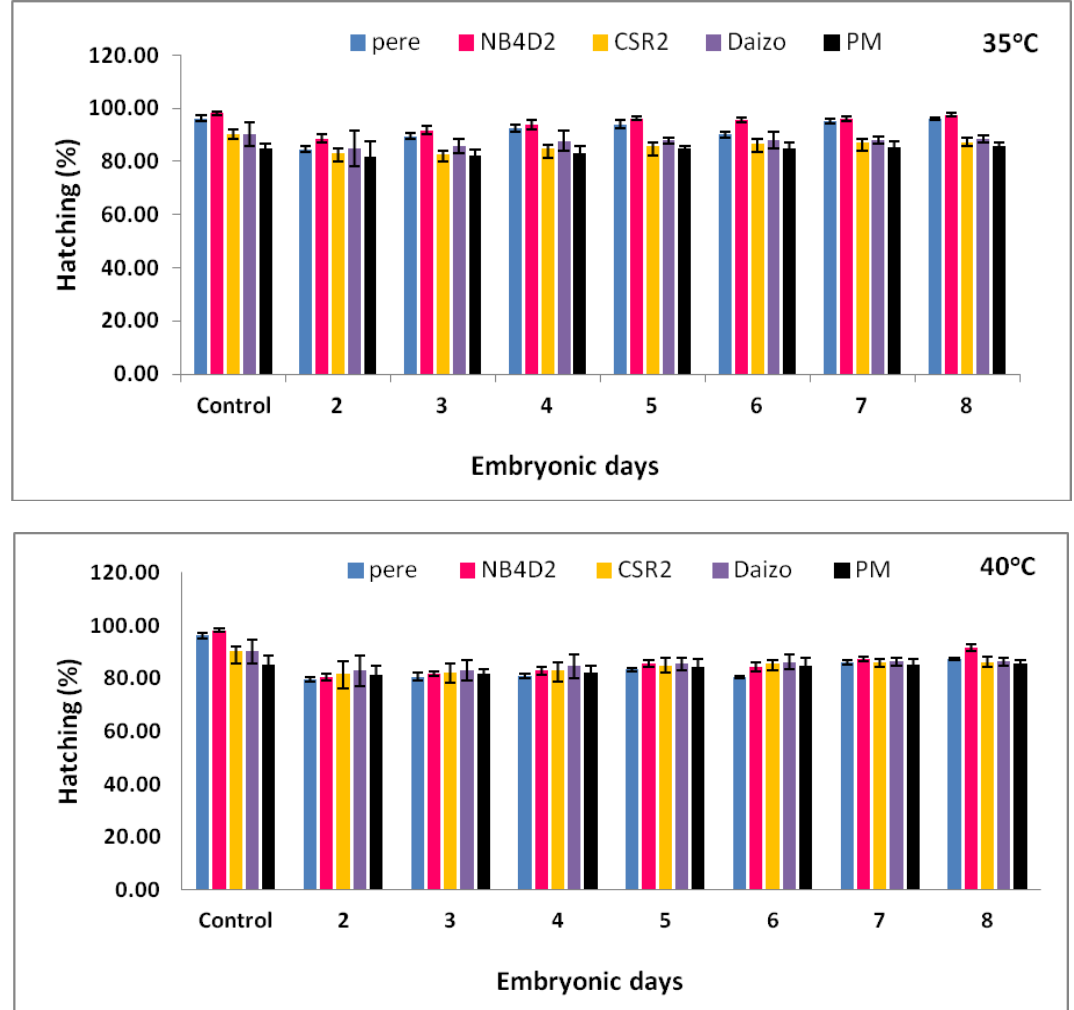

Fig. 5: Changes in the percent of hatching due to thermal stress during embryonic development in the poly-and bi-voltine silkworm strains of Bombyx mori. 
Table 3: Statistical analysis for the percent of hatching as influenced by heat shock during different days of eggs of poly and bivoltine silkworm strains of Bombyx mori.

\begin{tabular}{|c|c|c|c|c|c|c|}
\hline & & pere & NB4D2 & CSR2 & Daizo & PM \\
\hline \multirow{4}{*}{ F- Value } & Replications & 1.3649 & 1.1880 & 1.6749 & 3.8917 & 2.1163 \\
\hline & Temperature & 176214.9667 & 148255.8239 & 24572.3878 & 15832.2923 & 29170.2414 \\
\hline & Embryonic Days & 6282.4617 & 5082.9516 & 720.8441 & 426.7552 & 403.4994 \\
\hline & Temp. x Embryo Days & 3643.4095 & 3060.2497 & 503.1645 & 323.7403 & 597.1093 \\
\hline \multirow{3}{*}{ Significance } & Temperature & $*$ & $*$ & $*$ & $*$ & $*$ \\
\hline & Embryonic Days & $* *$ & $* *$ & $* *$ & $* *$ & $* *$ \\
\hline & Temp. x Embryo Days & $*$ & $*$ & $*$ & $*$ & $*$ \\
\hline \multirow{3}{*}{ SE } & Temperature & 0.1053 & 0.1180 & 0.2732 & 0.3458 & 0.2479 \\
\hline & Embryonic Days & 0.1720 & 0.1926 & 0.4461 & 0.5646 & 0.4048 \\
\hline & Temp. x Embryo Days & 0.2979 & 0.3337 & 0.7726 & 0.9780 & 0.7011 \\
\hline \multirow{3}{*}{ CD $5 \%$} & Temperature & 0.2919 & 0.3270 & 0.7571 & 0.9584 & 0.6871 \\
\hline & Embryonic Days & 0.4767 & 0.5340 & 1.2364 & 1.5651 & 1.1220 \\
\hline & Temp. x Embryo Days & 0.825 & 0.9249 & 2.1415 & 2.7108 & 1.9433 \\
\hline \multirow{3}{*}{ CV1\% } & Temperature & 0.3843 & 0.4304 & 0.9966 & 1.2616 & 1.4769 \\
\hline & Embryonic Days & 0.6275 & 0.7029 & 1.6275 & 2.0601 & 0.9044 \\
\hline & Temp. x Embryo Days & 1.0869 & 1.2175 & 2.8189 & 3.5682 & 2.5581 \\
\hline
\end{tabular}

\section{DISCUSSION}

The strong reasons why we have preferred the egg/embryonic stage of $B$. mori in the present study are because (a) any modifications that induced at the cellular level of an embryo by UV laser irradiation become visible either at pupal or adult stages or even in both stages [4,5,] but such events has not been reported in $B$. mori due to HS; (b) the structural changes reported at the pupal and adult stages due to exposure of embryos to high doses of UV laser radiation are well correlated with the manifestation of some important proteins as a function [6,7] and (c) since proteomic changes if any take place in the $B$. mori embryo due to hot events of the environment remain enigmatic.

To address these issues systematically, first we have constructed comprehensive embryonic proteome map for the first time to facilitate comparative analysis, in which all the embryos share approximately analogous proteins but their intensity varies among different silkworm strains of poly- and bi-voltines strains. Interestingly, the four major bands ascribable to vitelline- $\mathrm{H}$, egg specific protein, vitelline-L and $30 \mathrm{kDa}$ proteins despite similar in all the silkworm strains, but intensity of these protein bands vary which could be a relatable feature for comparative analysis among different silkworm strains/breeds. Number of protein bands not only variable at different developmental stages of embryos but also with the poly- (non diapause) and bi-volitine (diapause but acid treated) silkworm strains as has been reported from $24 \mathrm{~h}$ old embryos of diapause and non-diapause type eggs of $B$. mori following shotgun proteomic analysis [15]. In addition, the varied number and appearance of new proteins/bands are directly correlated with higher amount of protein content recorded between day-4 and day-6 embryos when compared to other stages (Fig. 3) clearly substantiate the process of organogenesis in which most of the internal organs start developing during this embryonic period [4]. Thus, we propose a strategy that the healthiness of the embryos shall be validated through a simple procedure - SDSPAGE before the eggs are taken for breeding work or distributed to farmers for commercial use. Since environmental fluctuation during embryonic development and larval growth has adverse effect on the fecundity and fertility [16] we have examined the effect of short period of heat shock treatment during embryogenesis. Eventually, the rate of hatching was significantly altered in all the days of eggs subjected to $\mathrm{HS}$ revealing $45^{\circ} \mathrm{C}$ as lethal temperature for all the silkworm strains. Between 35 and $40^{\circ} \mathrm{C}$, the hatching percentage was discretely differs with high mortality at $40^{\circ} \mathrm{C}$ when eggs were exposed for $2 \mathrm{~h}$ which is uncommon in both the poly- and bi- voltine silkworm strains, but it was found increased upon exposure to $30^{\circ} \mathrm{C}$ for $1 \mathrm{~h} \mathrm{[17]}$. Thus, the effect of HS is conspicuously found duration of the temperature and age of the strain dependent, which is quite significant as revealed by statistical analysis. Furthermore, discrete differences were also observed between 35 to $40^{\circ} \mathrm{C}$ with highest mortality at $40^{\circ} \mathrm{C}$ in early than late embryonic stages of all the silkworm strains studied as opinioned by Coulon and Mathelin [18]. Even Drosophila [19] and Plutella xylostella [20] eggs were also found highly sensitive to HS in their early developmental stage.

Interestingly, the expression of HSPs was not so obvious at the embryonic stage unlike larval stage of B. mori [14, 21], while presence of nine HSPs was identified thorough shotgun proteomic analysis [15] which are known to involve in the basic metabolic process, but are not inducible in due to environmental stresses [22]. In addition, genome-wide analysis while explicit the presence of 16 HSPs in the embryo of B. mori [23], the mRNA level as a fact of gene expression measured quantitatively was not correlated with the amount of HSPs synthesized [24] where they facilitate embryo development and metabolism by ensuing proteins properly folded and protecting against their denaturation [15] as reported in the present study. Augmenting, the expression of HSPs measured in larval and adult stages was also found higher than the egg stage of Ericerus pela [22] and HS in Drosophila eggs did not induce HSPs in early developmental stages [19]. The molecular mechanism in differential expression of HSPs in 
different developmental stages in the life cycle of any insects still remains obscure but shall be correlated with sensitivity of the embryo to a HS that lead to low hatchability as recorded in the present study. Concomitantly, embryonic death occurred in all the silkworm strains at $45^{\circ} \mathrm{C}$ HS temperature shall also be correlated with denature of $95,90,68,60,58,43,18$ and $19 \mathrm{kDa}$ proteins which were also confirmed through present densitometric analysis and supported by previous report [17]. It is true because certain sets of proteins (as reported above) requisite for the growth and development of the embryo has not been protected their folding by the synthesis of HSPs. Taken together, it is proved from the present study and previous reports that the embryonic stage is highly sensitive to temperature stress since the fecundity [2] and hatchability $[17,25,26]$ are greatly affected.

\section{CONCLUSION}

Since embryonic stage - the vital stage of the life span predetermines the post-embryonic traits of all organisms including B. mori we have established a comprehensive proteome map for the embryo of poly- and bi-voltines silkworm strains for comparative analysis. Exposure of varied stages of embryo to different HS temperatures no HSPs found expressed as has been reported in larvae [14, 27] but degradation of 18 and $19 \mathrm{kDa}$ proteins were distinct in all the days of embryos exposed to $45^{\circ} \mathrm{C}$ that could resulted in complete embryo death but some embryo found dead at the time of hatching. Thus, we strongly propose that hatching of embryo shall be one of the key traits for the determination of thermotolerance level of any silkworm strains. In addition, we also suggest that early embryonic stage shall be an appropriate stage to develop a quarantine disinfection treatment [27] that is heat treatment against agriculturally important lepidopteran pests because $B$. mori is considered as the central model system of Lepidoptera.

\section{ACKNOWLEDGMENTS}

Punyavathi thanks to DST for award of INSPIRE fellowship and MAB thanks to University of Mysore for granting NON-PHD fellowship and HBM thanks to the University Grants Commission for funding under MRP.

\section{Financial support and sponsorship: Nil.}

Conflict of Interests: There are no conflicts of interest.

\section{REFERENCES}

1. King AM, MacRae TH. Insect heat shock proteins during stress and diapause. Annu. Rev. Entomol. 2015; 60:59-75.

2. Nazia C, Mal Reddy N, Basavaraja HK, Dandin B. Alteration in qualitative and quantitative characters in bivoltine silkworm, Bombyx mori L. due to thermal stress. Indian J. Seric. 2005 1: 100-106.

3. Manjunatha HB, Rajesh RK, Aparna HS. Silkworm thermal biology: A review of heat shock response, heat shock proteins and heat acclimation in the domesticated silkworm, Bombyx mori. J. Insect Science. 2010; 10:204 available online: insectscience.org/10.204.

4. Tazima. In: The Silkworm: an important laboratory tool. (Ed. By Tazima Y) Kodansha Ltd., Tokyo. 1978; 213-245.

5. Myohara M. Fate mapping of the larval silk glands of Bombyx mori by UV laser irradiation of the egg at fertilization. Dev. Genes and Evol. 2003; 213:178-181.

6. Manjunatha HB, Hosagoudar SR, Inamdar SR. Biomolecular changes and somatic mutations induced by UV laser irradiation at embryonic stage of Bombyx mori. Int. J. Radiat. Biol. 2006; 82: 648-657.

7. Hosagoudar SR, Manjunatha HB. Picosecond UV laser induced morphological, biochemical and biological changes in Bombyx mori. Iran. J. Radiat. Res. 2011; 9: 127-137.

8. Walsh DA, Klein NW, Hightower LE, Edwards MJ. Heat shock and thermotolerance during early rat embryo development Teratology. 1987; 36: 181-191.

9. Potter KA, Davidowitz G, Woods HA. Cross-stage consequences of egg temperature in the insect Manduca sexta. Funct. Ecol. 2010; 1365: 2435.

10. Woods HA, Bonnecaze RT. Insect eggs at a transition between diffusion and reaction limitation: temperature, oxygen and water. J. Theor. Biol. 2006; 243: 483-492.

11. Narasimhanna MN. Manual on silkworm egg production. Central silk board, Bangalore. 1988; 110-111.

12. Lowry $\mathrm{OH}$, Rosebrough NJ, Farr AL, Randall RJ. Protein measurement with the Folin phenol reagent. J. Biol. Chem.1951; 193: 265-275.

13. Weber K, Osborn J. The reliability of molecular weight determination by dodecyl sulphate-polyacrylamide gel electrophoresis. J. Biol. Chem. 1969; 244: 4406-4412.

14. Vasudha BC, Aparna HS, Manjunatha HB. Impact of heat shock on heat shock proteins expression, biological and commercial traits of Bombyx mori. Insect Sci. 2006; 13: 243-250.

15. Fan L, Lin J, Zhong Y, Liu J. Shotgun proteomic analysis on the diapause and non-diapause eggs of domesticated silkworm Bombyx mori. PLoS ONE 2013; 4:e60386. doi:10.1371/journal.pone.0060386.

16. Suresh Kumar N, Harjeet Singh. Evaluation of the reproductive potential of bivoltine silkworm hybrids of Bombyx mori L under high temperature and high humidity and high temperature and low humidity conditions of the tropics. Univ. J. Environ. Res. Tech. 2012; 2: 443-449.

17. Manjunatha HB, Zamood A, Vasudha BC, Aparna HS. Heat shock response and analysis of egg proteins in new bivoltine strains of Bombyx mori. Sericologia. 2005; 45:403-408.

18. Coulon BM, Mathelin J. Variations in the rate of synthesis of heat shock proteins HSP70, between laying and neurula, the diapausing embryo of the silkworm Bombyx mori. Sericologia. 1991; 31: 295-300.

19. Welte MA, Tetrault JM, Dellavalle RP, Lindquist S. A new method for manipulating Trans genes: engineering heat tolerance in a complex, multi-cellular organism. Curr. Biol. 1993; 3: 842853.

20. Ebrahimi N, Talebi AA, Fathipour Y. Effects of short-term heat shock of eggs on the development and fecundity of Plutella xylostella (L.) (Lepidoptera: Plutellidae). J. Crop Prot. 2015; 1: 73-83.

21. Aparna HS, Kundapur RR, Manjunatha HB. Molecular characterization of heat shock proteins 90 (HSP83?) and 70 in tropical strains of Bombyx mori. Proteomics 2010; 10: 27342745.

22. Liu WW, Yang $\mathrm{P}$, Chen $\mathrm{XM}, \mathrm{Xu} \mathrm{DL}, \mathrm{Hu}$ YH. Cloning and expression analysis of four heat shock protein gene in Ericrus plea (Homoptera: Coccidae), J. Insec. Sci. 2014; 14: 142. 
23. Li ZW, Li X, Yu QY, Xiang ZH, Kishino H, Zhang Z. The small heat shock protein (sHSP) genes in the silkworm, Bombyx mori, and comparative analysis with other insect sHSP genes. BMC Evol. Biol 2009; 9:215.

24. Sasibhushan S, Ponnuvel KM, Vijayaprakash NB. Diapause specific gene expression in the eggs of multivoltine silkworm Bombyx mori, identified by suppressive subtractive hybridization. Comp. Biochem. Physiol. 2012; B 161:371-79.

25. Joy O, Gopinathan KP. Heat shock response in mulberry silkworm races with different thermotolerances, J. Biosci. 1995; 20: 499-513.

26. Taha RH. Impact of thermal stress on the haemolymphal proteins, biological and economical characters of the silkworm, Bombyx mori L. Egypt. Acad. J. Biolog. Sci. 2013; 1: 113-122.

27. Dohino T, Mizuno T, Mizuniwa S, Yoneda M, Miyazaki I. Heat and cold tolerance of various aged eggs of Bactrocera dorsalis and B. cucurbitae (Diptera: Tephritidae). Res. Bull. Pl. Prot. Japan. 2014; 50: 63-69.

\section{How to cite this article:}

Punyavathi, Bhat MA, Manjunatha HB. Comparative proteome. Comparative proteome analysis and thermal stress induced changes in the embryo of poly- and bi-voltine strains of Bombyx mori. J App Biol Biotech. 2017; 5 (02): 059-067. 